\title{
Legemiddelgjennomgang - viktig tiltak for bedre behandling
}

\author{
Legemiddelskader kan i stor grad forebygges med enkle tiltak. Et slikt tiltak er legemiddelgjennomgang, \\ og nå har Legemiddelverket laget en sjekkliste for legemiddelgjennomgang. Vi oppfordrer leger, særlig \\ fastleger, til aktiv bruk av denne metoden for å forebygge legemiddelskader.
}

Ingen vet nøyaktig hvor mange pasienter som skades eller dør på grunn av uheldig legemiddelbruk. Et nøkternt anslag er at minst 1000 personer årlig dør på grunn av legemidler i Norge. Det er rimelig å tro at omtrent halvparten av legemiddelskadene kan forebygges (1). Legene har en nøkkelrolle i forebyggingen av skader, siden de har ansvaret for at diagnose, valg av legemiddel og oppfølging er riktig.

Vi mener et av de største problemene $\mathrm{i}$ helsevesenet er mangelen på oversikt over legemiddelbruken til den enkelte pasient. Særlig utsatt er pasienter som bytter omsorgsnivå mellom fastlege, spesialist, sykehus eller sykehjem. Hos alle pasienter med komplisert legemiddelbehandling er det viktig at det regelmessig gjøres en grundig vurdering av behandlingen. Her har fastlegen et særlig ansvar. Fra mai 2013 har fastlegene en egen takst for legemiddelgjennomgang (takst 2ld). Tall vi har innhentet fra HELFO viser at taksten ble brukt 60366 ganger i 2013. Flertallet av pasientene der taksten ble brukt var eldre pasienter, og $75 \%$ var over 60 år. Taksten kan brukes en gang $i$ året hos pasienter som fast bruker fire eller flere legemidler.

\section{Legemiddelgjennomgang}

Vår erfaring er at mange leger strever med å skille mellom legemiddelsamstemming og legemiddelgjennomgang. Legemiddelsamstemming vil si å sette opp en full-

\section{«Et av de største pro- blemene i helsevesenet er mangelen på over- sikt over legemiddel- bruken til den enkelte pasient»}

stendig liste over alle medisiner pasienten bruker, inkludert reseptfrie medisiner, naturlegemidler og kosttilskudd. En slik liste er grunnlaget for neste trinn: legemiddelgjennomgangen.

Legemiddelgjennomgangen skal bidra til at pasienten får behandling som er best mulig tilpasset totalsituasjonen, inkludert psykososiale forhold og pasientens egne ønsker. Avhengig av situasjonen kan legemiddelgjennomgang være alt fra en enkel samtale med pasienten til en omfattende prosess med pasient, pårørende $\mathrm{og}$ annet helsepersonell (2-5).

Tankegangen bak en legemiddelgjennomgang illustreres av følgende eksempel: En kvinne i 80-årene ble henvist til fastlegen for utredning av fallårsak etter et fall som førte til et håndleddsbrudd, som ble gipset på legevakten. Ved siden av andre undersøkelser, ble det gjort en legemiddelgjennomgang som ga resultat som vist i tabell 1 .

\section{Sjekkliste for legemiddelgjennomgang}

Legemiddelverket lanserer i disse dager Sjekkliste for legemiddelgjennomgang (5). Listen er utviklet i samarbeid med Helsedirektoratet og Pasientsikkerhetsprogrammet. Den er en kortfattet veiledning på to sider, som inneholder sjekkpunkter og en liste på 14 «signallegemidler» som man skal være spesielt oppmerksomme på. Listen tok form gjennom et faglig dugnadsprosjekt med fastleger, sykehusleger, farmakologer og kliniske farmasøyter.

Praktisk erfaring fra klinisk arbeid og

Tabell 1 Eksempel på legemiddelgjennomgang hos en kvinne i 80-årene

Legemiddelbruk før legemiddelgjennomgang

Metoprolol, langtidsvirkende tablett $100 \mathrm{mg}$ daglig

Warfarin, 21 tabletter per uke

Simvastatin, 20 mg til kvelden

Hydroklortiazid, 25 mg én gang daglig

Alendronat, 70 mg en gang i uken

Diazepam, 5 mg inntil to ganger daglig

Zopiklon, 7,5 mg til kvelden
Symptom/funn/problem relatert til legemidlet

Langsom puls, tendens til ortostatisk hypotensjon

Risiko for blødninger ved fall

Mulig interaksjon med warfarin

Ingen problemer, ikke plaget med svelgvansker

Bidrar til ustøhet og falltendens

Bidrar til ustøhet og falltendens
Litt lavt serum-kalium, ortostatisk hypotensjon

\section{Kommentar/tiltak}

Hadde infarkt for 20 år siden, ingen angina eller svikt. Dose redusert til 50 mg $\times 1$ i første omgang

Fikk warfarin i forbindelse med infarkt. Byttet til acetylsalisylsyre $75 \mathrm{mg} \times 1$

Ingen tiltak, selv om virkningen av simvastatin er usikker i hennes alder

Usikkert hvorfor hun brukte denne medisinen, avsluttet behandlingen foreløpig

Fortsette med behandlingen

Uheldig medisin hos eldre, skiftet til oksazepam som har kortere halveringstid, ikke fast bruk

Skal forsøke å ta oksazepam til kvelden mot angst og søvnvansker i stedet for både benzodiazepin og z-sovemiddel

Forsterker virkningen av metoprolol, pilokarpin gir redusert syn
Sendt forespørsel til øyelegen om annen behandling 
undervisning tilsier at sjekklister og kortversjoner fungerer bedre i en travel hverdag enn omfattende retningslinjer og veiledere. Spesielt for studenter, leger og andre helsearbeidere som er ukjente med metoden, tror vi sjekklisten er en enkel og rask innføring. Sjekklisten bygger blant annet på START/ STOP-kriteriene (6), NorGeP (7) og HARM-studien (1). Det er også lagt vekt på forbrukstall fra Reseptregisteret ved utvelgelsen av «signallegemidlene». Sjekklisten vil bli revidert regelmessig, blant annet etter innspill fra brukerne. Vi planlegger også en nettversjon med søkefunksjoner.

\section{Fremtidsønsker}

Vi mener det haster med å etablere en nasjonal legemiddeljournal som til enhver tid gir behandlende lege korrekte sanntidsopplysninger om pasientens legemiddelbruk. Det tror vi vil spare liv og store ressurser. Innføring av e-resept er et skritt i riktig retning, og kjernejournalen som nå er under utprøvning, vil være nok et viktig skritt på veien mot nasjonal legemiddeljournal. Mangel på oversikt og mangel på elektronisk kommunikasjon gjør det vanskelig å etablere samarbeid mellom ulike faggrupper.

I tillegg må pasientene kunne få adgang til sine egne data. Det er ikke bare legene og andre helsearbeidere som må samarbeide om bedre legemiddelbehandling. En nasjo- nal legemiddeljournal kan frigjøre tid som legene nå bruker til gjentatt legemiddelsamstemming, tid som med hell kan brukes til personlig pasientveiledning. Da vil pasienten kunne ta et større medansvar og oppleve bedre mestring av egen sykdom og livssituasjon.

\section{Morten Finckenhagen \\ Sigurd Hortemo \\ Steinar Madsen \\ steinar.madsen@legemiddelverket.no}

Morten Finckenhagen (f. 1955) er spesialist i allmennmedisin, overlege ved Statens legemiddelverk og praksiskonsulent ved Bærum sykehus. Han har vært prosjektleder ved utarbeidingen av sjekklisten.

Forfatter har fylt ut ICMJE-skjemaet og oppgir ingen interessekonflikter.

Sigurd Hortemo (f. 1954) er spesialist i allmennmedisin og i samfunnsmedisin, overlege ved Statens legemiddelverk og er fastlege. Forfatter har fylt ut ICMJE-skjemaet og oppgir ingen interessekonflikter.

Steinar Madsen (f. 1956) er spesialist i indremedisin og i hjertesykdommer og medisinsk fagdirektør ved Statens legemiddelverk. Forfatter har fylt ut ICMJE-skjemaet og oppgir ingen interessekonflikter.
Litteratur

1. Leendertse AJ, Egberts AC, Stoker LJ et al. Frequency of and risk factors for preventable medication-related hospital admissions in the Netherlands. Arch Intern Med 2008; 168: 1890-6.

2. Helsedirektorat. Veileder om legemiddelgjennomganger. www.helsedirektoratet.no/publikasjoner/ veileder-om-legemiddelgjennomganger/Sider/ default.aspx (24.7.2014)

3. Norsk legemiddelhåndbok. G24 Legemiddelgjennomgang (LMG). www.legemiddelhandboka.no/ Generelle/311096 [24.7.2014].

4. Madsen S. Legemiddelgjennomgang og bedre legemiddelbruk. Utposten 2014; 43: 20-2

5. Statens legemiddelverk. Legemiddelgjennomgang. www.legemiddelverket.no/Bruk og raad/ Raad_til_helsepersonell/Legemiddelgjennomgang/ Sider/default.aspx (24.7.2014)

6. Gallagher P, Ryan C, Byrne S et al. STOPP (Scree ning Tool of Older Person's Prescriptions) and START (Screening Tool to Alert doctors to Right Treatment). Consensus validation. Int J Clin Pharmacol Ther 2008; 46: 72-83.

7. Rognstad S, Brekke M, Fetveit A et al. The Norwegian General Practice (NORGEP) criteria for assessing potentially inappropriate prescriptions to elderly patients. A modified Delphi study. Scand J Prim Health Care 2009; 27: 153-9.

Mottatt 5.7. 2014, første revisjon innsendt 24.7. 2014, godkjent 24.7. 2014. Redaktør: Hanne Støre Valeur.

Publisert først på nett. 